\title{
Low expression of c-Myc protein predicts poor outcomes in patients with hepatocellular carcinoma after resection
}

\author{
Fei $\mathrm{Ji}^{1+} \mathbb{B}$, Zhi-heng Zhang ${ }^{2 \dagger}$, Yi Zhang ${ }^{3 \dagger}$, Shun-Li Shen ${ }^{4}$, Qing-Hua Cao ${ }^{5}$, Long-Juan Zhang ${ }^{6}$, Shao-Qiang Li ${ }^{4}$, \\ Bao-Gang Peng ${ }^{4}$, Li-Jian Liang ${ }^{4}$ and Yun-Peng Hua ${ }^{4 *}$
}

\begin{abstract}
Background: Embryonic Liver Fodrin (ELF) is an adaptor protein of transforming growth factor (TGF- $\beta$ ) signaling cascade. Disruption of ELF results in mislocalization of Smad3 and Smad4, leading to compromised TGF- $\beta$ signaling. c-Myc is an important oncogenic transcription factor, and the disruption of TGF- $\beta$ signaling promotes c-Mycinduced hepatocellular carcinoma (HCC) carcinogenesis. However, the prognostic significance of c-Myc in HCC is less understood

Methods: The expression of c-Myc protein and mRNA were measured by immunohistochemistry (IHC) and qRT$P C R$, respectively. IHC was performed to detect TGF- $\beta 1$ and ELF expression in HCC tissues. Their relationship with clinicopathological factors and overall survival (OS) and disease free survival (DFS) were examined.

Results: The expression of c-Myc protein and mRNA in HCC tissues were significantly higher in HCC area than those in normal liver tissues. However, the expression were low compared with those adjacent to HCC area. c-Myc protein was independently predictive of DFS and OS, and it was negatively correlated with tumor size $(P=0.031)$, tumor number $(P=0.038)$, and recurrence $(P=0.001)$. Low c-Myc expression was associated with short-term recurrence and poor prognosis. The predictive value of c-Myc combined with TGF- $\beta 1$ or/and ELF was higher than that of any other single marker. Low c-Myc, high TGF- $\beta 1$ or/and low ELF expression was associated with the worst DFS and OS.

Conclusions: Low expression of c-Myc protein predicts poor outcomes in patients with HCC with hepatectomy. The combination of the expression of c-Myc, TGF- $\beta 1$, and ELF can be used to accurately predict outcomes of patients with HCC.
\end{abstract}

Keywords: C-MYC, Oncogene, Hepatocellular carcinoma, Prognosis, Biomarkers

\section{Background}

Hepatocellular carcinoma (HCC) is a very common and serious malignancy with high morbidity and high mortality. It is the sixth most common cancer and the third common cause of cancer-related death worldwide [1-3] Though most cases of HCC happen in Eastern Asia and sub-Saharan Africa, the incidence in some developed countries such as Japan, UK, France, and

\footnotetext{
* Correspondence: hyp0427@163.com

${ }^{\dagger}$ Equal contributors

${ }^{4}$ Department of Liver Surgery, The First Affiliated Hospital, Sun Yat-sen University, Guangzhou 510080, People's Republic of China

Full list of author information is available at the end of the article
}

USA is increasing [4] The increase of incidence and the lack of effective treatment for HCC have made the disease a major health problem [5]. Therefore, it is important to understand the mechanisms of $\mathrm{HCC}$ to find the effective biomarkers and to develop therapies.

c-Myc, an important oncogenic transcription factor, locates on chromosome 8q24.1, and involves in cell proliferation, apoptosis, differentiation and metabolism because it participates in the regulation of $15 \%$ of all genes in the human genome, including microRNAs [6-12]. Furthermore, as a powerful cancer-promoting oncogene, c-Myc has been implicated in the pathogenesis of kinds of malignant tumors, including human solid tumor, leukemia and

(c) The Author(s). 2018 Open Access This article is distributed under the terms of the Creative Commons Attribution 4.0 International License (http://creativecommons.org/licenses/by/4.0/), which permits unrestricted use, distribution, and reproduction in any medium, provided you give appropriate credit to the original author(s) and the source, provide a link to the Creative Commons license, and indicate if changes were made. The Creative Commons Public Domain Dedication waiver (http://creativecommons.org/publicdomain/zero/1.0/) applies to the data made available in this article, unless otherwise stated. 
lymphoma, along with animal tumors [13-17]. Similarly, c-Myc is also identified as a reasonable gene driver and a central regulator of malignant transformation in primary stages of HCC carcinogenesis using gene expression profiling of cirrhotic and dysplastic nodules, and early HCC [18]. In addition, c-Myc gene is commonly found to be overexpressed in advanced $\mathrm{HCC}$ tissues and derived HCC cell lines too $[19,20]$. Moreover, regression of invasive HCC in animal models could be induced by the inactivation of c-Myc gene, followed by up-regulation of liver cell and liver stem cell markers, and down-regulation of tumor markers [21].

Paradoxically, c-Myc is also found to induce apoptosis and cell senescence, and represent tumor-suppressive through activation of tumor suppressor p53 directly or indirectly [12, 17]. The recent studies indicate that tumorigenesis in mouse models of c-Myc oncogenesis was accelerated by inactivation of the ARF-MDM2-p53 pathway. c-Myc can also change the balance of pro- and anti-apoptotic factors to prime the cells for apoptosis and death [6, 22, 23]. Pelengaris et al. [24] used a switchable form of the c-Myc protein to make a reversible transgenic model of pancreatic $\beta$ cell oncogenesis, and found that loss of c-Myc protein up-regulated Bcl-xL expression and suppressed apoptosis, finally resulted in a full spectrum of tumor development, even distant metastasis. Murakami et al. [25] and Lee et al. [26] found that c-Myc-induced HCC was marked by a relatively higher degree of cell differentiation, less aggressiveness, a lower rate of genomic instability, and a longer time for carcinogenesis. Other studies have also reported that the level of c-Myc expression determined its oncogenic potential, indicated that low c-Myc expression induced cell proliferation and oncogenesis, whereas high c-Myc expression activated pro-apoptotic programs and accelerated apoptosis [27-29].

In this study, we investigated the prognostic value of cMyc expression in in patients with HCC undergoing curative resection. In addition, it is well-known that overexpression of TGF- $\beta 1$ correlates with carcinogenesis and progression of HCC. We have observed that the high level of TGF- $\beta 1$ and low level of ELF (a Smad3/4 adaptor protein) predicted the poor outcome in patients with HCC [30-32]. Santoni-Rugiu et al. [33] indicated that disruption of TGF$\beta 1$ signaling promoted c-Myc- induced HCC carcinogenesis by TGF- $\alpha$ as well. Therefore, this study further verified the more accurate predictive parameters of HCC using the combination of c-Myc with TGF- $\beta 1$, and ELF.

\section{Methods}

\section{Study population}

This study was approved by the Ethics Review Committee of the First Affiliated Hospital of Sun Yat-sen University. Eighty-four patients with HCC receiving hepatectomy at our center from June 2007 to October 2009 were included in this study. The inclusion criteria were patients: 1) with tumor-node-metastasis (TNM) stage I, II, IIIA or IIIB (International Union Against Cancer, the seventh edition); 2) with ChildPugh class A and class B hepatic function; 3) aged 18-80; and 4) provided written informed consent. The exclusion criteria included patients: 1) with TNM stage IIIC, IVA, or IVB; 2) with Child-Pugh class C hepatic function; 3) with second malignancy or history of second malignancy within 5 years; 4) with perioperative dysfunction of vital organs; 5 ) with percutaneous ablation, 6) transcatheter arterial chemoembolization (TACE); and 7) received chemotherapy, or radiotherapy within 1 month post-operation. All patients were postoperatively followed-up as described in our previous study [30]. Normal liver tissues, HCC adjacent tissues, and HCC tissues were collected and prepared as described in previous study [30].

\section{Immunohistochemical analysis}

Immunohistochemical analysis was performed as previously described [30]. Rabbit polyclonal anti-c-Myc antibody (ab32072, Abcam, USA) was used in the immunohistochemical analysis (1:100 dilution).

\section{Evaluation of Immunohistochemical staining}

The immunohistochemical staining in the tissue was scored independently by 2 pathologists blinded to the patients and clinical data, by applying a semiquantitative immunoreactivity score (IRS) reported elsewhere [30]. Category A documented the intensity of immunostaining as $0-3$ ( 0 , negative; 1 , weak; 2 , moderate; 3 , strong). Category $\mathrm{B}$ documented the percentage of immunoreactive cells as 0 (less than 5\%), $1(6 \%-25 \%)$, 2 (26\%-50\%), 3 (51\%-75\%), and 4 (76\%-100\%). Multiplication of category A and B resulted in an IRS ranging from 0 to 12 for each tumor or non-tumor. Sections with a total score of 0 or 1 or 2 were defined as negative (-), score of 3 or 4 were defined as weakly positive $(+)$, score of 6 or 8 were defined as moderately positive $(++)$, score of 9 or 12 were defined as strongly positive $(+++)$. For categorical analyses, the immunoreactivity was graded as low level (total score $<=4$ ) or high level (total score $>4$ ).

\section{Real -time quantitative polymerase chain reaction (qRT- PCR)}

Fresh HCC tissues $(n=29)$, HCC adjacent tissues $(n=29)$, and normal liver tissues $(n=4)$ were collected immediately after resection for detecting c-Myc mRNA expression. RNA was extracted by TRIzol reagent (Thermo Fisher Scientific, MA, USA) according to manufacturer's protocol. The cDNA was synthesized by cDNA synthesis 
kit (Takara Biotechnology, Japan) in accordance with manufacturer's instructions. The cDNA was used as templates for qRT-PCR by the SYBR Green PCR kit (Toyobo, Japan) in the Bio-rad IQ5 PCR system (Bio-Rad, CA). GAPDH was used as an internal control. The relative gene expressions were quantified and analyzed. The primers were obtained from Genecopia Company (Guangzhou, China).

\section{Statistical analysis}

Normally distributed Continuous variables were compared by Student's t-test. Categorical variables were compared with Chi-square test. Disease free survival (DFS) was defined as the interval from the surgery to recurrence, while overall survival (OS) was defined as the interval from surgery to the HCC-associated death. The univariate, multivariate and Kaplan-Meier method was used to analyze the survival rates [34], and the equivalences of the survival curves were compared among groups by log-rank test. A $P$-value $<0.05$ would be regarded as statistical significance in each test. All analyses were performed using SPSS v 13 software (Chicago, IL, USA).

\section{Results}

The expression of c-Myc protein and mRNA in HCC and adjacent tissues

The expression of c-Myc in normal liver tissues was negative $(0 / 20)$. However, c-Myc protein was expressed in 78. $5 \%(66 / 84)$ in HCC tissues and in $82.1 \%(69 / 84)$ in adjacent tissues, and these rates were significantly different from that of normal liver tissues $(P<0.001)$. In adjacent tissues and HCC tissues, the high expression $(++$ to +++$)$ rates for c-Myc were $65.5 \%$ (55/84) and 59.5\% (50/84), respectively, and there were no statistical difference between them $(P=0.426)$ (Table 1, Fig. 1$)$.

Similarly, we observed that the levels of c-myc mRNA in HCC tissues and in adjacent tissues were higher than that in normal liver tissues $(P=0.002$ and $\mathrm{P}<0.001$, respectively). Interestingly, we found the level of c-myc mRNA in HCC tissues was remarkably lower than those in the corresponding adjacent tissue $(\mathrm{P}<0.001)$. HCC tissues were divided into two groups in terms of TNM stage: Early stage HCC (TNM stage I and tumor size less than $10 \mathrm{~cm}, n=17$ ) , and advanced HCC (TNM stage II and III, $n=12$ ). There was no striking difference in c-myc mRNA

Table 1 The expression of c-Myc in HCC

\begin{tabular}{|c|c|c|c|}
\hline \multirow[t]{2}{*}{ Group } & \multirow[t]{2}{*}{ N } & \multicolumn{2}{|c|}{ Expression of C-MYC } \\
\hline & & High (++ +++) & $\operatorname{Low}(-\sim+)$ \\
\hline Normal liver tissues & 20 & $0(0.0 \%)$ & $20(100.0 \%)$ \\
\hline Adjacent tissues $^{\mathrm{a}}$ & 84 & $55(65.5 \%)$ & $29(34.5 \%)$ \\
\hline HCC tissues $^{a}$ & 84 & $50(59.5 \%)$ & $34(40.5 \%)$ \\
\hline
\end{tabular}

expression between the early stage $\mathrm{HCC}$ and advanced HCC (Fig. 1).

Correlation between 15 clinicopathological characteristics and c-Myc protein expression in HCC and adjacent tissues To better understand the importance of the prognostic value of c-Myc protein expression, we first analyzed the relationships between 15 clinicopathological characteristics and c-Myc protein expression in cancer tissues (Table 2). The results showed that the expression of c-Myc protein in tumor tissues was not associated with age, sex, serum HBsAg positivity, serum alanine aminotransferase (ALT), and AFP level. There was also no relation between $\mathrm{c}-\mathrm{Myc}$ expression and tumor differentiation, TNM stage, completeness of tumor encapsulation, and postoperative complications. However, the level of c-Myc protein in HCC tissues was positively correlated with cirrhosis $(P=0.042)$, but negatively correlated with platelet (PLT) count $(P=0.036)$, tumor number $(P=0.038)$, portal vein tumor thrombosis (PVTT) $(P=0.019)$, tumor size $(P=0.031)$, and recurrence $(P=0.002)$.

In tissues adjacent to $\mathrm{HCC}$, high expression of c-Myc was only associated with complete tumor encapsulation $(P=0.006)$.

\section{Independent prognostic factors of HCC}

In order to discern the factors related to DFS and OS, cMyc and clinicopathological factors were assessed by univariate analysis and the Multivariate analysis. The univariate analysis indicated that significant prognostic factors for DFS were PVTT, tumor number, tumor encapsulation, blood transfusion, blood loss, operative time, TNM stage, and c-Myc expression. The significant prognostic factors for OS were PVTT, tumor number, resection margin, tumor size, tumor differentiation, TNM stage, blood transfusion, blood loss, operative time and c-Myc expression (all $P<0.05$ ) (Table 3). Multivariate analysis indicated that blood transfusion, TNM stage and c-Myc expression were significantly independent prognostic factors for both DFS and OS (all $\mathrm{P}<0.05$ ). (Table 4).

\section{Low expression of c-Myc predicts short-term recurrence} and the poor outcomes in patients with HCC.

All patients were divided into 2 groups in terms of their c-Myc expression profiles: high-expression $(n=50)$ and low-expression $(n=34)$. Analysis showed that c-Myc expression level was positively correlated with DFS and OS. The 1-, 3-, and 5-year DFS rates in the high c-Myc expression group were significantly higher than those of low expression group $(70.0 \%, 54.9 \%, 45.9 \%$ vs. $17.6 \%, 11$. $8 \%, 11.8 \%$, respectively, $P<0.001$ ) (Fig. $2 \mathrm{a}$ ). In addition, the 1-, 3-, and 5-year OS rates of the high expression 


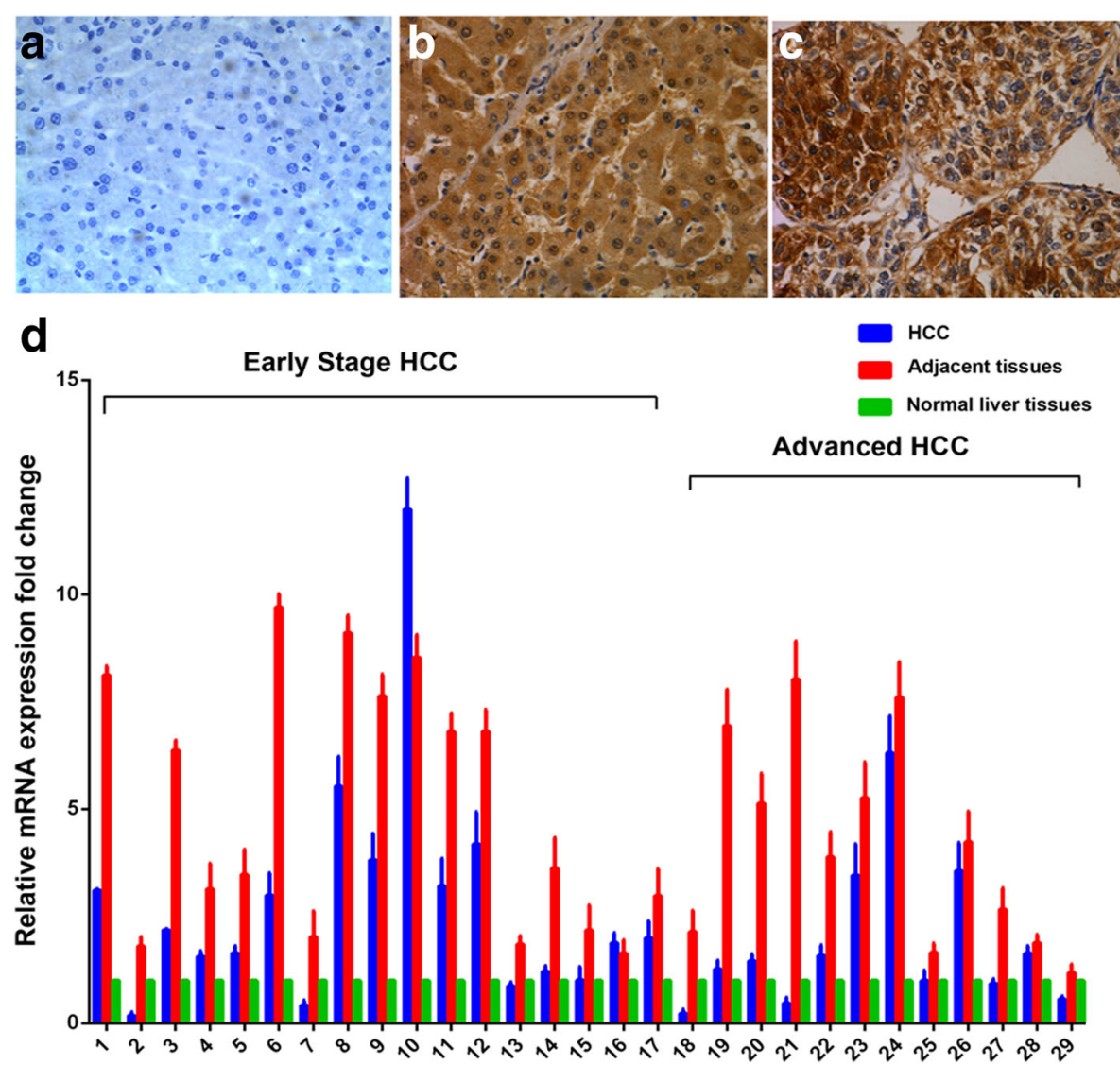

Fig. 1 Expression of c-Myc. Immunohistochemical staining in different tissues is shown. Normal liver tissues (a), HCC adjacent tissues (b), HCC tissues (c) (original magnification $\times 400$ ), and expression of c-Myc mRNA (d)

group were still markedly higher than those of low expression group $(92.0 \%, 72.0 \%, 62.0 \%$ vs. $64.7 \%, 20.6 \%$, $14.7 \%$, respectively, $\mathrm{P}<0.001$ ) (Fig. 2b).

In the current study, the total recurrence rate was $67.9 \%$ (57/84); however, 43 cases of recurrence happened in the first postoperative year. The 1-, 3-, and 5 -year OS rates of the in patients with $\mathrm{HCC}$ with a recurrence in first year $(62.8 \%, 20.9 \%, 9.3 \%$, respectively) were obviously lower than that of patients with a recurrence after 1 years $(100 \%, 50.0 \%, 35.7 \%$, respectively, $\mathrm{P}<0.001$ ), or those without recurrence $(100 \%, 100 \%, 100 \%, \quad \mathrm{P}<0.001)$. There was also a marked difference rates between patients with a recurrence after 1 year and those without a recurrence ( $\mathrm{P}<0.001$, Fig. 3).

We then analyzed the association between c-Myc expression and recurrence time, and found that the proportion of patients with low c-Myc expression with short term recurrence $(62.8 \%)$ was higher than that in patients with a long term recurrence $(14.3 \%$, $P=0.002)$ or without recurrence $(14.8 \%, P<0.001)$. However, there was no apparent difference between patients with a long term recurrence and patients with no recurrence $(P=0.964)$ (Table 5).

\section{Combining c-Myc expression with TGF- $\beta 1$ or/and ELF reveals improved prognostic accuracy for HCC}

As described in our previous study [30], high level of ELF protein (a Smad3/4 adaptor protein) was observed in normal liver tissues and low level of ELF protein in HCC tissues (Fig. 4a, b). In contrast, high level of TGF$\beta 1$ protein was found in human HCC tissues and low level of TGF- $\beta 1$ protein in normal liver tissues (Fig. 4c, d). Then, we demonstrated a significant negative correlation between c-Myc and TGF- $\beta 1(r=-0.228, P=0.037$, Table 6), and a significant positive correlation between c-Myc and ELF $(r=0.217, P=0.048$, Table 7$)$. We also analyzed the prognostic value of combined TGF- $\beta 1$ and $\mathrm{c}-\mathrm{Myc}$ levels for HCC. We divided patients into the following four groups: TGF- $\beta 1$ high expression/cMyc high expression (ThMh), TGF- $\beta 1$ low expression/c-Myc high expression (TlMh), TGF- $\beta 1$ high expression/c-Myc low expression (ThMl), TGF- $\beta 1$ low expression /c-Myc low expression (TlMl). Analysis 
Table 2 Correlation between c-Myc and the clinicopathological characteristics in HCC tissues and adjacent tissues

\begin{tabular}{|c|c|c|c|c|c|c|c|}
\hline \multirow[t]{2}{*}{ Variables } & \multirow[t]{2}{*}{ Cases } & \multicolumn{2}{|c|}{ c-Myc expression in HCC tissues } & \multirow[t]{2}{*}{$P$ value } & \multicolumn{2}{|c|}{ c-Myc expression in adjacent tissues } & \multirow[t]{2}{*}{$P$ value } \\
\hline & & Low & High & & Low & High & \\
\hline \multicolumn{8}{|l|}{ Age(yrs) } \\
\hline$>=60$ & 16 & $4(25.0 \%)$ & $12(75.0 \%)$ & 0.161 & $3(18.8 \%)$ & $13(81.2 \%)$ & 0.140 \\
\hline$<60$ & 68 & $30(44.1 \%)$ & $38(55.9 \%)$ & & $26(38.2 \%)$ & $42(61.8 \%)$ & \\
\hline \multicolumn{8}{|l|}{ Sex } \\
\hline Male & 68 & $29(42.6 \%)$ & $39(57.4 \%)$ & 0.403 & $21(30.9 \%)$ & $47(69.1 \%)$ & 0.148 \\
\hline Female & 16 & $5(31.3 \%)$ & $11(68.7 \%)$ & & $8(50.0 \%)$ & $8(50.0 \%)$ & \\
\hline \multicolumn{8}{|l|}{$\mathrm{HbsAg}$} \\
\hline Positive & 72 & $30(41.7 \%)$ & $42(58.3 \%)$ & 0.586 & $25(34.7 \%)$ & $47(65.3 \%)$ & 0.925 \\
\hline Negative & 12 & $4(33.3 \%)$ & $8(66.7 \%)$ & & $4(33.3 \%)$ & $8(66.7 \%)$ & \\
\hline \multicolumn{8}{|l|}{$\operatorname{ALT}(\mathrm{U} / \mathrm{L})$} \\
\hline$\geq 80$ & 9 & $3(33.3 \%)$ & $6(66.7 \%)$ & 0.644 & $5(55.6 \%)$ & $4(44.4 \%)$ & 0.160 \\
\hline$<80$ & 75 & $31(41.3 \%)$ & $44(58.7 \%)$ & & $24(32.0 \%)$ & $51(68.0 \%)$ & \\
\hline \multicolumn{8}{|l|}{$\operatorname{PLT}\left(\times 10^{9}\right)$} \\
\hline$>100$ & 74 & $33(44.6 \%)$ & $41(55.4 \%)$ & 0.036 & $24(32.4 \%)$ & $50(67.6 \%)$ & 0.273 \\
\hline$\leq 100$ & 10 & $1(10.0 \%)$ & $9(90.0 \%)$ & & $5(50.0 \%)$ & $5(50.0 \%)$ & \\
\hline \multicolumn{8}{|l|}{ Cirrhosis } \\
\hline Yes & 64 & $22(34.4 \%)$ & $42(65.6 \%)$ & 0.042 & 19(29.7\%) & 45(70.3\%) & 0.095 \\
\hline No & 20 & $12(60.0 \%)$ & $8(40.0 \%)$ & & $10(50.0 \%)$ & $10(50.0 \%)$ & \\
\hline \multicolumn{8}{|l|}{ AFP(ug/L) } \\
\hline$\geq 20$ & 48 & $22(45.8 \%)$ & $26(51.2 \%)$ & 0.248 & 19(39.6\%) & $29(60.4 \%)$ & 0.260 \\
\hline$<20$ & 36 & 12(33.3\%) & $24(66.7 \%)$ & & $10(27.8 \%)$ & $26(72.2 \%)$ & \\
\hline \multicolumn{8}{|c|}{ Tumor size $(\mathrm{cm})$} \\
\hline$\geq 5$ & 50 & $25(50.0 \%)$ & $25(50.0 \%)$ & 0.031 & 19(38.0\%) & $31(62.0 \%)$ & 0.416 \\
\hline$<5$ & 34 & $9(26.5 \%)$ & $25(73.5 \%)$ & & $10(29.4 \%)$ & $24(70.6 \%)$ & \\
\hline \multicolumn{8}{|c|}{ Tumor number } \\
\hline Single & 62 & $21(33.9 \%)$ & $41(66.1 \%)$ & 0.038 & $20(32.3 \%)$ & $42(67.7 \%)$ & 0.463 \\
\hline Multiple & 22 & 13(59.1\%) & $9(40.9 \%)$ & & $9(40.9 \%)$ & 13(59.1\%) & \\
\hline \multicolumn{8}{|c|}{ Differentiation } \\
\hline$|-| \mid$ & 62 & 24(38.7\%) & $38(61.3 \%)$ & 0.580 & $25(40.3 \%)$ & $37(59.7 \%)$ & 0.061 \\
\hline III & 22 & $10(45.5 \%)$ & $12(54.5 \%)$ & & $4(18.2 \%)$ & 18(81.8\%) & \\
\hline \multicolumn{8}{|l|}{ TNM stage } \\
\hline 1 & 55 & $20(36.4 \%)$ & $35(63.6 \%)$ & 0.290 & 18(32.7\%) & $37(67.3 \%)$ & 0.633 \\
\hline$\|-\| \|$ & 29 & 14(48.3\%) & 15(51.7\%) & & $11(37.9 \%)$ & 18(62.1\%) & \\
\hline \multicolumn{8}{|l|}{ PVTT } \\
\hline Yes & 11 & $8(72.7 \%)$ & $3(27.3 \%)$ & 0.019 & $4(36.4 \%)$ & $7(63.6 \%)$ & 0.890 \\
\hline No & 73 & $26(35.6 \%)$ & $47(64.4 \%)$ & & $25(34.2 \%)$ & $48(65.8 \%)$ & \\
\hline \multicolumn{8}{|c|}{ Tumor Encapsulation } \\
\hline Complete & 64 & 23(35.9\%) & $41(64.1 \%)$ & 0.130 & $17(26.6 \%)$ & $47(73.4 \%)$ & 0.006 \\
\hline None & 20 & $11(55.0 \%)$ & $9(45.0 \%)$ & & $12(60.0 \%)$ & $8(40.0 \%)$ & \\
\hline \multicolumn{8}{|l|}{ Recurrence } \\
\hline Yes & 58 & $30(51.7 \%)$ & $28(48.3 \%)$ & 0.002 & $21(36.2 \%)$ & $37(63.8 \%)$ & 0.628 \\
\hline No & 26 & $4(15.4 \%)$ & $22(84.6 \%)$ & & $8(30.8 \%)$ & 18(69.2\%) & \\
\hline
\end{tabular}


Table 2 Correlation between c-Myc and the clinicopathological characteristics in HCC tissues and adjacent tissues (Continued)

\begin{tabular}{lllllll}
\hline Variables & Cases & \multicolumn{2}{c}{$c$ c-Myc expression in HCC tissues } & $P$ value & c-Myc expression in adjacent tissues & $P$ value \\
\hline Complication & & & & & \\
No & 73 & $27(37.0 \%)$ & $46(63.0 \%)$ & 0.177 & $27(37.0 \%)$ & $46(63.0 \%)$ \\
Yes & 11 & $7(63.6 \%)$ & $4(36.4 \%)$ & & $2(18.2 \%)$ & 9.221 \\
\hline
\end{tabular}

AFP Alpha-fetoprotein, ALT alanine aminotransferase, HBSAg hepatitis B surface antigen, PLT platelet, PVTT portal vein tumor thrombi

exhibited that the TlMh group had the best OS. The DFS and the TIMl groups had the second best rates, followed by the ThMh group, and the worst prognosis was seen in the ThMl group.

The 1-, 3-, and 5-year DFS rates of the TlMh group $(88.9 \%, 81.5 \%, 70.2 \%$, respectively) were markedly higher than those of ThMh group $(47.8 \%, 21.7 \%, 17.4 \%$, respectively, $P<0.001)$ and the ThMl group $(11.5 \%, 3.8 \%$, $3.8 \%$,respectively, $\mathrm{P}<0.001$ ). The $1-, 3$-, and 5 -year OS rates of the TlMh group $(96.3 \%, 92.6 \%, 85.2 \%$,respectively) were obviously higher than those of the ThMh group $(87.0 \%, 47.8 \%, 34.8 \%$,respectively, $\mathrm{P}<0.001)$ and the ThMl group $(57.7 \%, 11.5 \%, 7.7 \%$,respectively, $\mathrm{P}<0$. 001) (Fig. 5a, b). Furthermore, the 1-, 3- and 5-year DFS rates of the ThMl group were remarkably lower than those of the ThMh group $(P=0.004)$ and TlMl group $(42.9 \%, 42.9 \%, 42.9 \%$, respectively, $\mathrm{P}=0.004)$. The $1-$, 3 -, and 5-year OS rates of the ThMl group were markedly lower than those of the ThMh group $(P=0.001)$ and TlMl group (42.9\%, 42.9\%, 2.9\%, respectively, $P=0.012$ ). Moreover, there was a significant difference of OS between the TlMh group and TlMl group $(P=0.007)$ (Fig. 5a, b). Overall, the results showed that the combination of TGF- $\beta 1$ elevation and c-Myc reduction in HCC tissues seems to be predictive of poorest prognosis.

Second, we divided patients into another four groups in order to analyze the prognostic value of combined ELF and c-Myc levels for patients with HCC: ELF high expression/c-Myc high expression (EhMh), ELF low expression/c-Myc high expression (ElMh), ELF high expression/c-Myc low expression (EhMl), ELF low expression/c-Myc low expression (ElMl). The analysis indicated that the EhMh group had the best OS and DFS rates, the ElMh group the second best, followed by the EhMl group, and the ElMl group had the worst prognosis.

The 1-, 3-, and 5-year DFS rates of EhMh group (89.3\%, 71.4\%, 64.3\%, respectively) were markedly higher than those of the ElMh group $(45.5 \%, 31.8 \%$, $22.7 \%$, respectively, $P<0.001)$ and the ElMl group (4. $5 \%, 0 \%, 0 \%$, respectively, $\mathrm{P}<0.001)$. The $1-, 3-$, and 5 -year OS rates of the EhMh group (100\%,85.7\%, 78. $6 \%$, respectively) were significantly higher than those of the EhMl group (66.7\%, 41.7\%, 33.3\%,respectively, $\mathrm{P}<0.001)$ and the ElMl group $(63.6 \%, 9.1 \%$, and 4 . 5\%,respectively, $\mathrm{P}<0.001$ ) (Fig. 6a, b). The 1-, 3-, and 5year DFS rates of the ElMl group were remarkably lower than those of the ElMh group $(P=0.003)$ and the EhMl group $(41.7 \%, 33.3 \%$, and $33.3 \%$, respectively, $P=0.010)$. The 1-, 3-, and 5-year OS rates of the ElMl group were markedly lower than those of the ElMh group (81.8\%, 54 . $5 \%, 40.9 \%$, respectively, $P=0.002$ ). Moreover, there was a significant difference in OS between the EhMh and ElMh group $(P=0.003)$ (Fig. 6a, b). Overall, the results indicated that the combination of elevation of both ELF and c-Myc in HCC tissues seems to be predictive of the best prognosis.

Finally, we observed the predictive effect of c-Myc expression combined with TGF- $\beta 1$ and ELF for outcomes in patients with $\mathrm{HCC}$ through analysis of the following eight groups: TGF- $\beta 1$ high/ELF high/c-Myc high expression (ThEhMh), TGF- $\beta 1 /$ ELF low/c-Myc high expression (ThElMh), TGF- $\beta 1$ high/ELF high/cMyc low expression (ThEhMl), TGF- $\beta 1$ high/ELF low/ c-Myc low expression (ThElMl), TGF- $\beta 1$ low/ELF high/c-Myc high expression (TlEhMh), TGF- $\beta 1$ low/ ELF high/c-Myc low expression (TIEhMl), TGF- $\beta 1$ low/ELF low/c-Myc high expression(TlElMh), TGF- $\beta 1$ low/ELF low/c-Myc low expression (TlEIMl).

The 1-, 3-, and 5-year OS rates of the TlEhMh group $(100 \%, 94.7 \%, 89.5 \%$, respectively) were the best, and significantly higher than those of the ThEhMh $(100.0 \%, 66$. $7 \%$, 55.6\%, respectively, $P=0.026)$, ThElMh $(78.6 \%, 35$. 7\%, 21.4\%, respectively, $P<0.001)$, ThEhMl $(57.1 \%, 14$. $3 \%$, 14.3\%, respectively, $P<0.001)$, TlElMl $(100 \%, 0 \%$, $0 \%$, respectively, $\mathrm{P}<0.001)$, and ThElMl groups $(60.0 \%$, $10.0 \%, 5.0 \%, \mathrm{P}<0.001)$. Similarly, the 1-, 3-, and 5-year OS rates of the TlElMh group $(87.5 \%, 87.5 \%, 75.0 \%$, respectively) were also remarkably higher than those of the ThElMh $(\mathrm{P}=0.020)$, ThEhMl $(\mathrm{P}<0.001)$, TIElMl $(P=0$. 029), and ThElMl groups $(P<0.001)$. The $1-, 3$-, and 5 -year OS rates of the TlEhMl group $(80.0 \%, 80.0 \%, 60.0 \%$ respectively) were also higher than those of the ThElMl group ( $P$ $=0.011$ ). The 1-, 3-, and 5-year OS rates of the ThEhMh group were also significantly higher than those of the ThEhMl $(P=0.038)$, and ThElMl group $(P=0.001)$. However, there was no significant difference of OS between the other two groups $(P>0.05)$.

The 1-, 3-, and 5-year DFS rates of the TlEhMh group $(94.7 \%, 84.2 \%, 78.9 \%$, respectively) were significantly 
Table 3 Prognostic factors for DFS and OS by univariate analysis

\begin{tabular}{|c|c|c|c|c|c|c|c|c|c|}
\hline \multirow[t]{2}{*}{ Variables } & \multirow[t]{2}{*}{$n$} & \multicolumn{3}{|l|}{ DFS } & \multirow[t]{2}{*}{ P } & \multicolumn{3}{|l|}{ OS } & \multirow[t]{2}{*}{$P$} \\
\hline & & $1-y r$ & $3-y r s$ & 5 -yrs & & $1-y r$ & $3-y r s$ & 5 -yrs & \\
\hline \multicolumn{10}{|l|}{ Sex } \\
\hline Male & 68 & $47.1 \%$ & $36.8 \%$ & $30.5 \%$ & 0.433 & $79.4 \%$ & $50.0 \%$ & $41.2 \%$ & 0.478 \\
\hline Female & 16 & $56.3 \%$ & $37.5 \%$ & $37.5 \%$ & & $87.5 \%$ & $56.3 \%$ & $50.0 \%$ & \\
\hline \multicolumn{10}{|l|}{ Age(yrs) } \\
\hline$<60$ & 68 & $45.6 \%$ & $32.4 \%$ & $27.7 \%$ & 0.104 & $82.4 \%$ & $48.5 \%$ & $39.7 \%$ & 0.391 \\
\hline$\geq 60$ & 16 & $62.5 \%$ & $56.3 \%$ & $49.2 \%$ & & $75.0 \%$ & $62.5 \%$ & $56.3 \%$ & \\
\hline \multicolumn{10}{|l|}{$\operatorname{PLT}\left(\times 10^{9}\right)$} \\
\hline$<100$ & 10 & $80.0 \%$ & $60.0 \%$ & $60.0 \%$ & 0.053 & $100 \%$ & $80.0 \%$ & $70.0 \%$ & 0.076 \\
\hline$\geq 100$ & 74 & $44.6 \%$ & $33.8 \%$ & $28.0 \%$ & & $78.4 \%$ & $47.3 \%$ & $39.2 \%$ & \\
\hline \multicolumn{10}{|l|}{$\mathrm{HbsAg}$} \\
\hline Positive & 72 & $47.2 \%$ & $38.9 \%$ & $33.0 \%$ & 0.700 & $79.2 \%$ & $50.0 \%$ & $44.4 \%$ & 0.882 \\
\hline Negative & 12 & $58.3 \%$ & $25.0 \%$ & $25.0 \%$ & & $91.7 \%$ & $58.3 \%$ & $33.3 \%$ & \\
\hline \multicolumn{10}{|l|}{ AFP( $\mu \mathrm{g} / \mathrm{L})$} \\
\hline$<20$ & 36 & $52.8 \%$ & $38.9 \%$ & $38.9 \%$ & 0.336 & $83.3 \%$ & $50.0 \%$ & $44.4 \%$ & 0.750 \\
\hline$\geq 20$ & 48 & $45.8 \%$ & $35.4 \%$ & $26.3 \%$ & & $79.2 \%$ & $52.1 \%$ & $41.7 \%$ & \\
\hline \multicolumn{10}{|l|}{ Ascites } \\
\hline No & 68 & $52.9 \%$ & $39.7 \%$ & $35.0 \%$ & 0.093 & $83.8 \%$ & $51.5 \%$ & $44.1 \%$ & 0.551 \\
\hline Yes & 16 & $31.3 \%$ & $25.0 \%$ & $18.8 \%$ & & $68.8 \%$ & $50.0 \%$ & $37.5 \%$ & \\
\hline \multicolumn{10}{|l|}{ Cirrhosis } \\
\hline No & 24 & $45.0 \%$ & $35.0 \%$ & $30.0 \%$ & 0.685 & $95.0 \%$ & $60.0 \%$ & $45.0 \%$ & 0.485 \\
\hline Yes & 60 & $50.0 \%$ & $37.5 \%$ & $32.4 \%$ & & $76.6 \%$ & $48.4 \%$ & $42.2 \%$ & \\
\hline \multicolumn{10}{|c|}{ Tumor number } \\
\hline Single & 62 & $59.7 \%$ & $43.5 \%$ & $36.7 \%$ & 0.002 & $85.5 \%$ & $61.3 \%$ & $51.6 \%$ & $<0.001$ \\
\hline Multiple & 22 & $18.2 \%$ & $18.2 \%$ & $18.2 \%$ & & $68.2 \%$ & $22.7 \%$ & $18.2 \%$ & \\
\hline \multicolumn{10}{|l|}{ PVTT } \\
\hline No & 73 & $54.8 \%$ & $41.1 \%$ & $35.3 \%$ & $<0.001$ & $87.7 \%$ & $56.2 \%$ & $47.9 \%$ & $<0.001$ \\
\hline Yes & 11 & $9.1 \%$ & $9.1 \%$ & $9.1 \%$ & & $36.4 \%$ & $18.2 \%$ & $9.1 \%$ & \\
\hline \multicolumn{10}{|c|}{ Tumor size $(\mathrm{cm})$} \\
\hline$<5$ & 34 & $64.7 \%$ & $47.1 \%$ & $41.2 \%$ & 0.055 & $97.1 \%$ & $67.6 \%$ & $52.9 \%$ & 0.040 \\
\hline$\geq 5$ & 50 & $38.0 \%$ & $30.0 \%$ & $25.7 \%$ & & $70.0 \%$ & $40.0 \%$ & $36.0 \%$ & \\
\hline \multicolumn{10}{|c|}{ Tumor Encapsulation } \\
\hline None & 20 & $30.0 \%$ & $25.0 \%$ & $15.0 \%$ & 0.013 & $60.0 \%$ & $45.0 \%$ & $30.0 \%$ & 0.081 \\
\hline Complete & 64 & $54.7 \%$ & $40.6 \%$ & $37.3 \%$ & & $87.5 \%$ & $53.1 \%$ & $46.9 \%$ & \\
\hline \multicolumn{10}{|c|}{ Resection margin } \\
\hline$<2 \mathrm{~cm}$ & 45 & $40.0 \%$ & $26.7 \%$ & $24.4 \%$ & 0.106 & $80.0 \%$ & $40.0 \%$ & $28.9 \%$ & 0.007 \\
\hline$\geq 2 \mathrm{~cm}$ & 39 & $59.0 \%$ & $48.7 \%$ & $40.5 \%$ & & $82.1 \%$ & $64.1 \%$ & $59.0 \%$ & \\
\hline \multicolumn{10}{|l|}{ Complication } \\
\hline No & 73 & $49.3 \%$ & $38.4 \%$ & $32.8 \%$ & 0.407 & $84.9 \%$ & $53.4 \%$ & $45.2 \%$ & 0.095 \\
\hline Yes & 11 & $45.5 \%$ & $27.3 \%$ & $27.3 \%$ & & $54.5 \%$ & $36.4 \%$ & $27.3 \%$ & \\
\hline \multicolumn{10}{|c|}{ Tumor differetiation } \\
\hline$|-| \mid$ & 62 & $54.8 \%$ & $41.9 \%$ & $35.0 \%$ & 0.212 & $85.5 \%$ & $56.5 \%$ & $48.4 \%$ & 0.037 \\
\hline III-IV & 22 & $31.8 \%$ & $22.7 \%$ & $22.7 \%$ & & $68.2 \%$ & $36.4 \%$ & $27.3 \%$ & \\
\hline
\end{tabular}

Blood inflow occlusion 
Table 3 Prognostic factors for DFS and OS by univariate analysis (Continued)

\begin{tabular}{|c|c|c|c|c|c|c|c|c|c|}
\hline \multirow[t]{2}{*}{ Variables } & \multirow[t]{2}{*}{$n$} & \multicolumn{3}{|l|}{ DFS } & \multirow[t]{2}{*}{$P$} & \multicolumn{3}{|l|}{ OS } & \multirow[t]{2}{*}{$P$} \\
\hline & & $1-y r$ & 3-yrs & 5 -yrs & & $1-\mathrm{yr}$ & 3 -yrs & 5 -yrs & \\
\hline Yes & 31 & $41.9 \%$ & $29.0 \%$ & $20.7 \%$ & \multirow[t]{2}{*}{0.182} & $77.4 \%$ & $48.4 \%$ & $35.5 \%$ & \multirow[t]{2}{*}{0.300} \\
\hline No & 53 & $52.8 \%$ & $41.5 \%$ & $37.7 \%$ & & $83.0 \%$ & $52.8 \%$ & $47.2 \%$ & \\
\hline \multicolumn{10}{|c|}{ Blood transfusion } \\
\hline Yes & 25 & $20.0 \%$ & $4.0 \%$ & $4.0 \%$ & \multirow[t]{2}{*}{$<0.001$} & $56.0 \%$ & $12.0 \%$ & $4.0 \%$ & \multirow[t]{2}{*}{$<0.001$} \\
\hline No & 59 & $61.0 \%$ & $50.8 \%$ & $43.7 \%$ & & $91.5 \%$ & $67.8 \%$ & $59.3 \%$ & \\
\hline \multicolumn{10}{|c|}{ Blood loss (mL) } \\
\hline$\leq 1000$ & 73 & $54.8 \%$ & $42.5 \%$ & $36.7 \%$ & \multirow[t]{2}{*}{$<0.001$} & $86.3 \%$ & $58.9 \%$ & $49.3 \%$ & \multirow[t]{2}{*}{$<0.001$} \\
\hline$>1000$ & 11 & $9.1 \%$ & $0.0 \%$ & $0.0 \%$ & & $45.5 \%$ & $0.0 \%$ & $0.0 \%$ & \\
\hline \multicolumn{10}{|c|}{ Operative time(min) } \\
\hline$\leq 180$ & 42 & $66.7 \%$ & $54.8 \%$ & $47.3 \%$ & \multirow[t]{2}{*}{$<0.001$} & $92.9 \%$ & $73.8 \%$ & $64.3 \%$ & \multirow[t]{2}{*}{$<0.001$} \\
\hline$>180$ & 42 & $31.0 \%$ & $19.0 \%$ & $16.7 \%$ & & $69.0 \%$ & $28.6 \%$ & $21.4 \%$ & \\
\hline \multicolumn{10}{|l|}{ TNM stage } \\
\hline । & 55 & $60.0 \%$ & $43.6 \%$ & $39.7 \%$ & \multirow[t]{2}{*}{0.002} & $90.9 \%$ & $60.0 \%$ & $52.7 \%$ & \multirow[t]{2}{*}{0.001} \\
\hline$\|-I\|$ & 29 & $27.6 \%$ & $24.1 \%$ & $17.2 \%$ & & $62.1 \%$ & $34.5 \%$ & $24.1 \%$ & \\
\hline \multicolumn{10}{|l|}{ c-Myc } \\
\hline Low & 34 & $17.6 \%$ & $11.8 \%$ & $11.8 \%$ & \multirow[t]{2}{*}{$<0.001$} & $64.7 \%$ & $20.6 \%$ & $14.7 \%$ & \multirow[t]{2}{*}{$<0.001$} \\
\hline High & 50 & $70.0 \%$ & $54.0 \%$ & $45.9 \%$ & & $92.0 \%$ & $72.0 \%$ & $62.0 \%$ & \\
\hline
\end{tabular}

AFPAlpha-fetoprotein, ALT alanine aminotransferase, $H B s A g$ hepatitis B surface antigen, PLT platelet, PVTT portal vein tumor thrombi

higher than those of the ThEhMh $(77.8 \%, 44.4 \%, 33.3 \%$, $P=0.003)$, ThEhMl $(28.6 \%, 14.3 \%, 14.3 \%$, respectively, $\mathrm{P}$ $<0.001)$, ThElMh (28.6\%, 7.1\%,7.1\%, respectively, $\mathrm{P}<0$. 001), ThElMl $(5.0 \%, 0.0 \%, 0.0 \%$, respectively, $\mathrm{P}<0.001)$, and TlElMl groups $(0 \%, 0 \%, 0 \%$, respectively, $\mathrm{P}<0.001)$. The 1-, 3-, and 5-year DFS rates of the TlElMh group (75.0\%, 75.0\%, 50.0\%, respectively) were also significantly higher than those of the ThEhMl $(P=0.024)$, ThElMh $(P=0.009)$, ThElMl $(\mathrm{P}<0.001)$, and TlElMl $(\mathrm{P}=0.029)$ groups. Likewise, the 1-, 3-, and 5-year DFS rates of the TlEhMl group $(60.0 \%, 60.0 \%, 60.0 \%$, respectively) were also significantly higher than those of the ThElMl $(P=0.007)$ and TlElMl group $(P=0.057)$. The 1-, 3-, and 5-year DFS rates of the ThEhMh group were also significantly higher than those of the ThEhMl $(P=0.037)$, ThElMh $(P=0.021)$, ThElMl $(\mathrm{P}<0.001)$, and TlElMl $(P=0.004)$ groups. However, there was no obvious difference of DFS between the other two groups $(\mathrm{P}>0.05)$ (Fig. 7).

\section{Discussion}

Undoubtedly, c-Myc plays an important role in the occurrence and development of HCC. For example, overexpression of the c-Myc gene has been frequently observed in human HCC tissues. And c-Myc has induced the occurrence of $\mathrm{HCC}$ in animal models. Accordingly, c-Myc inhibition results in a loss of the neoplastic properties [18-21]. However, c-Myc also exhibits onco-suppressive activity, such as apoptosis and cell senescence [12, 17, 22, 23]. Kaposi-Novak et al. [27], Akita et al. [28] and Murphy et al. [29] have shown that when c-Myc was at a low level, oncogenic properties were increased and proliferation was induced, once cMyc exceeded a threshold level, the upregulation of proapoptotic factors p53, p21, and p27 and cell death from apoptosis were detected.

There are few studies about the level of c-Myc protein in human HCC and adjacent tissues, or about the prognostic value of c-Myc protein in HCC. Cui et al. [35]

Table 4 Prognostic factors for disease-free and overall survival by the multivariate Cox proportional hazards regression model

\begin{tabular}{|c|c|c|c|c|c|c|}
\hline \multirow[t]{2}{*}{ Variables } & \multicolumn{3}{|l|}{ DFS } & \multicolumn{3}{|l|}{ OS } \\
\hline & $\mathrm{HR}$ & $95 \% \mathrm{Cl}$ & $P$ & $\mathrm{HR}$ & $95 \% \mathrm{Cl}$ & $P$ \\
\hline Blood transfusion & 1.922 & $1.017-3.635$ & 0.044 & 2.856 & $1.465-5.567$ & 0.002 \\
\hline TNM stage & 2.143 & $1.220-3.766$ & 0.008 & 2.191 & $1.169-4.108$ & 0.014 \\
\hline c-Myc & 0.364 & $0.194-0.686$ & 0.002 & 0.284 & $0.148-0.548$ & $<0.001$ \\
\hline
\end{tabular}

HR hazard ratio, $\mathrm{Cl}$ confidence interval 

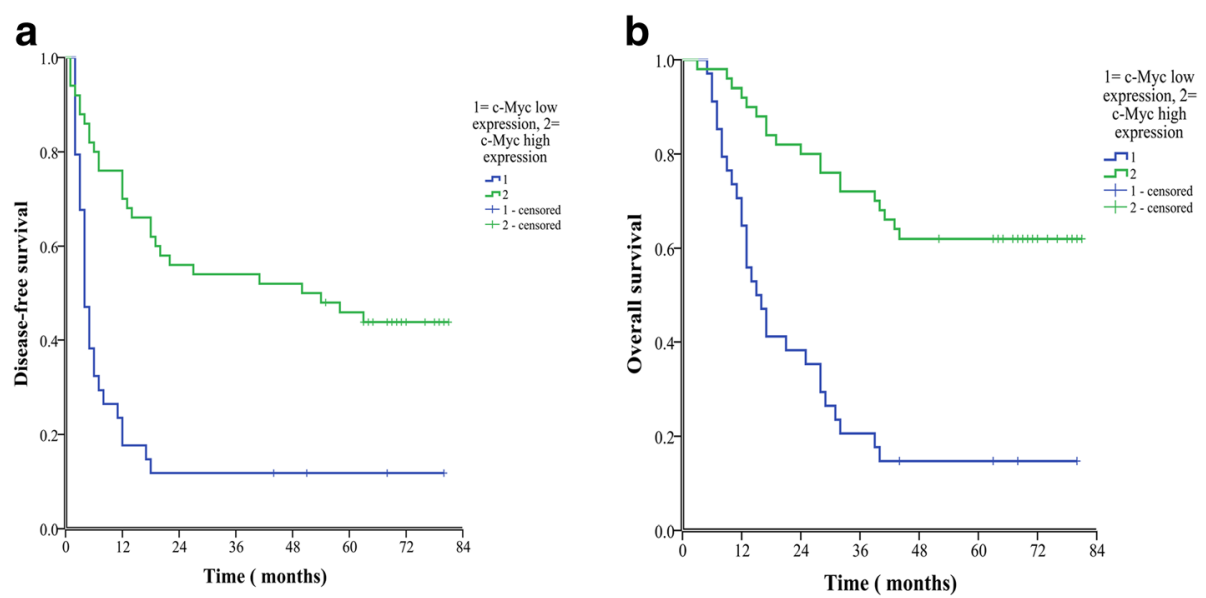

Fig. 2 Kaplan-Meier curves are shown for time to disease recurrence ( $\mathbf{a}, P<0.001$, log-rank test) and overall survival (b, $P<0.001$, log-rank test) among patients with high or low intratumoral c-Myc expression

found that there was higher c-Myc expression in $\mathrm{HCC}$ tissues with tumor recurrence within 1 year after tumor resection (15 cases), compared with that in HCC tissues without tumor recurrence (15 cases), and made a conclusion that high levels of c-Myc protein was related to a high recurrence rate. However, Yuen et al. [36] drew a completely different conclusion by analyzing the data of 150 patients with HCC. They found that the expression of $\mathrm{c}-\mathrm{Myc}$ protein was negatively correlated with the grade of tumor differentiation and the levels of mutated p53.

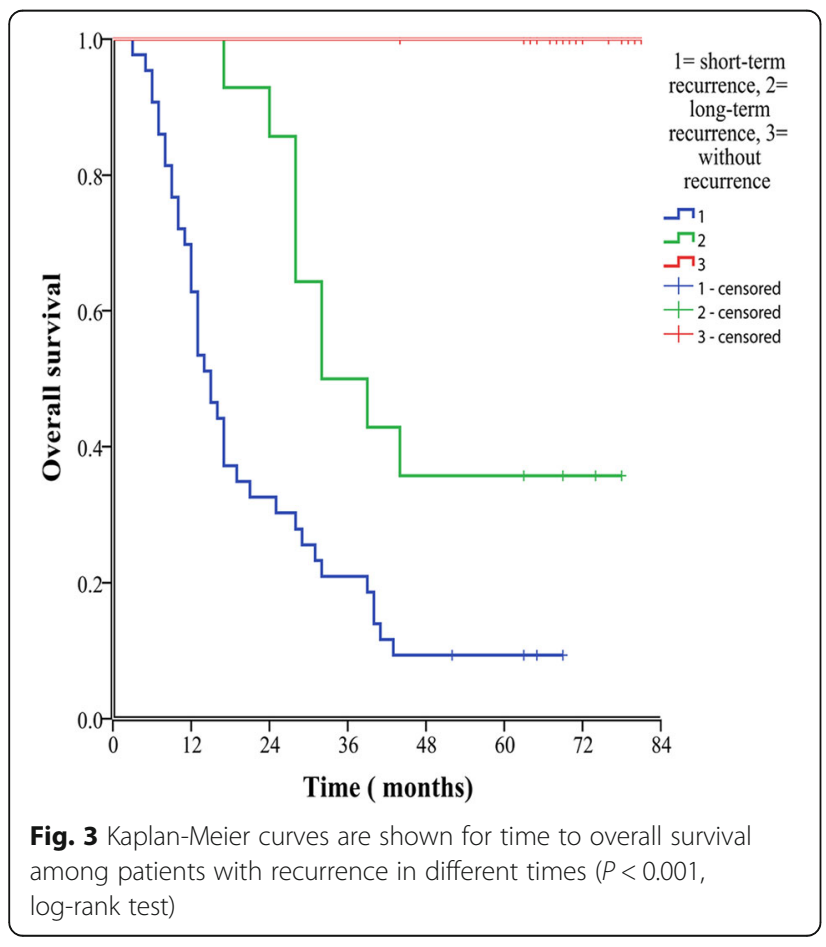

Our results showed that there was low expression of c-Myc protein and mRNA in normal liver tissue, while there was high expression in HCC and adjacent tissues. We also observed a phenomenon reported by Yuen et al. [36] that there was the higher expression of c-Myc protein and mRNA in adjacent tissues as compared to those of HCC tissues. Furthermore, we found that c-Myc protein in HCC tissues was negatively correlated with PVTT, tumor number, tumor size, and recurrence, whereas there were no correlation between clinicopathological characteristics and c-Myc expression in adjacent tissues except complete tumor encapsulation.

We further analyzed the clinical significance of c-Myc protein in the outcomes of patients with HCC, and found that the expression of c-Myc protein was a significant and independent prognostic factor for DFS and OS, and the predictive accuracy was better than that of TNM stage, another independent prognostic factor for HCC. The results showed that low expression of c-Myc protein predicts recurrence and the poor outcomes in patients with HCC. The 1-, 3-, and 5-year DFS and OS rates $(70.0 \%, 54$. $9 \%, 45.9 \%$ and $92.0 \%, 72.0 \%, 62.0 \%$, respectively) in patients with HCC with high c-Myc expression were remarkably higher than those with low c-Myc expression $(17.6 \%, 11.8 \%, 11.8 \%$ and $64.7 \%, 20.6 \%, 14.7 \%)$.

Table 5 The correlationship between c-Myc and recurrence

\begin{tabular}{llll}
\hline Recurrence & N & \multicolumn{2}{l}{$c$-Myc expression } \\
\cline { 3 - 4 } & & High & Low \\
\hline $0-1(y r s)^{a, b}$ & 43 & $16(37.2 \%)$ & $27(62.8 \%)$ \\
$>1(y r s)^{c}$ & 14 & $12(85.7 \%)$ & $2(14.3 \%)$ \\
No recurrence & 27 & $23(85.2 \%)$ & $4(14.8 \%)$ \\
\hline
\end{tabular}

a compared with $>1$ year recurrence, $P=0.002$

${ }^{\mathrm{b}}$ compared with no recurrence, $P<0.001$.

c compared with no recurrence, $P=0.964$ (by chi-square test) 


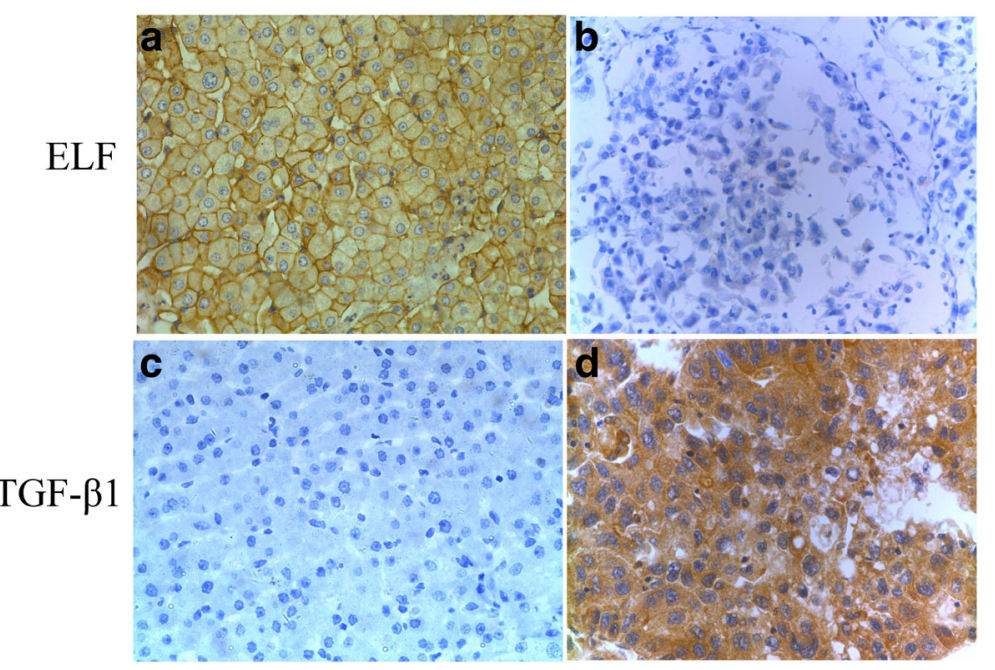

Fig. 4 Expression of ELF and TGF- $\beta 1$ immunohistochemical staining in different tissues is shown. Normal liver tissues $(\mathbf{a}, \mathbf{c})$, HCC tissues $(\mathbf{b}, \mathbf{d})$ (original magnification $\times 400$ )

It is well known that the recurrence of $\mathrm{HCC}$ after resection is intimately associated with a decreased median survival. Moreover, the recurrence within the first postoperative year predicted a worse prognosis [37]. We observed that low c-Myc expression in HCC tissues was also intimately associated with short-term recurrence and a lower OS rate, compared to those with the longterm recurrence and no recurrence. The proportion of low c-Myc expression in patients with HCC with recurrence at $\leq 1$ year was $62.8 \%$, which was remarkably higher than that in patients with HCC with a recurrence after 1 year and no recurrence $(14.3 \%$ and $14.8 \%$, respectively).

Overexpression of TGF- $\beta 1$ is usually found in HCC tissues, and it correlates with carcinogenesis and progression of HCC. Disruption of TGF- $\beta$ signaling is recognized as the key mechanism through which the function of TGF- $\beta$ is changed from tumor suppression to tumor promotion. Santoni-Rugiu et al. [33] indicated that c-Myc induced HCC carcinogenesis was strengthened by TGF- $\beta 1$ overexpression. Our previous studies $[30,32]$ showed high-expression of TGF- $\beta 1$ in rat HCC tissues, and abnormality of the TGF- $\beta 1$ signaling pathway might promote the carcinogenesis of HCC, also indicated that a high level of TGF- $\beta 1$ foreboded a poor prognosis of in patients with HCC after curative

Table 6 The correlationship between c-Myc and TGF- $\beta 1$ in HCC

\begin{tabular}{llllll}
\hline Myc & \multicolumn{1}{c}{ TGF- $\beta 1$} & & & $r$ & P value \\
\cline { 2 - 4 } & +++ & ++ & $-\sim+$ & & \\
\hline+++ & 7 & 5 & 12 & -0.228 & 0.037 \\
++ & 9 & 3 & 15 & & \\
$-\sim+$ & 15 & 11 & 7 & & \\
\hline
\end{tabular}

resection. The loss or down-regulation of ELF (a Smad3/ 4 adaptor protein) might be one of reasons for disruption of TGF- $\beta 1$ signaling, which similarly predicted a poor OS and DFS rate for patients with HCC. Interestingly, their combination had a better prognostic value, compared with either one alone.

In this study, we analyzed the correlation of c-Myc with TGF- $\beta 1$ and ELF, and found that $\mathrm{c}-\mathrm{Myc}$ was negatively associated with TGF- $\beta 1$ and positively with ELF. Intriguingly, the combination of c-Myc with ELF or/and TGF- $\beta 1$ increased predictive accuracy for outcomes in patients with HCC who underwent resection, and in particular the combination of all three.

Our results showed that patients with HCC with the best prognosis had low TGF- $\beta 1$ and high c-Myc expression (3-year OS and DFS rates of $92.6 \%$ and $81.5 \%$, respectively), while the worst prognosis was seen in patients who have high TGF- $\beta 1$ and low c-Myc expression (3-year OS and DFS rates of $11.5 \%$ and $3.8 \%$, respectively). The second best was in patients of low TGF- $\beta 1$ and low c-Myc expression (3-year OS and DFS rates of $42.9 \%$ and $42.9 \%$, respectively), and the third was in patients of high TGF- $\beta 1$ and high c-Myc expression (3-year OS and DFS rates of $47.8 \%$ and $21.7 \%$, respectively). So we can conclude that high TGF- $\beta 1$ or low c-Myc expression both predict poor prognosis in patients with $\mathrm{HCC}$, and this combination is

Table 7 The correlationship between c-Myc and ELF in HCC

\begin{tabular}{llllll}
\hline$c-$ & $E L F$ & & & $r$ & $P$ value \\
\cline { 2 - 4 } Myc & +++ & ++ & $-\sim+$ & & \\
\hline+++ & 12 & 1 & 11 & 0.217 & 0.048 \\
++ & 4 & 11 & 12 & & \\
$-\sim+$ & 7 & 5 & 21 & & \\
\hline
\end{tabular}



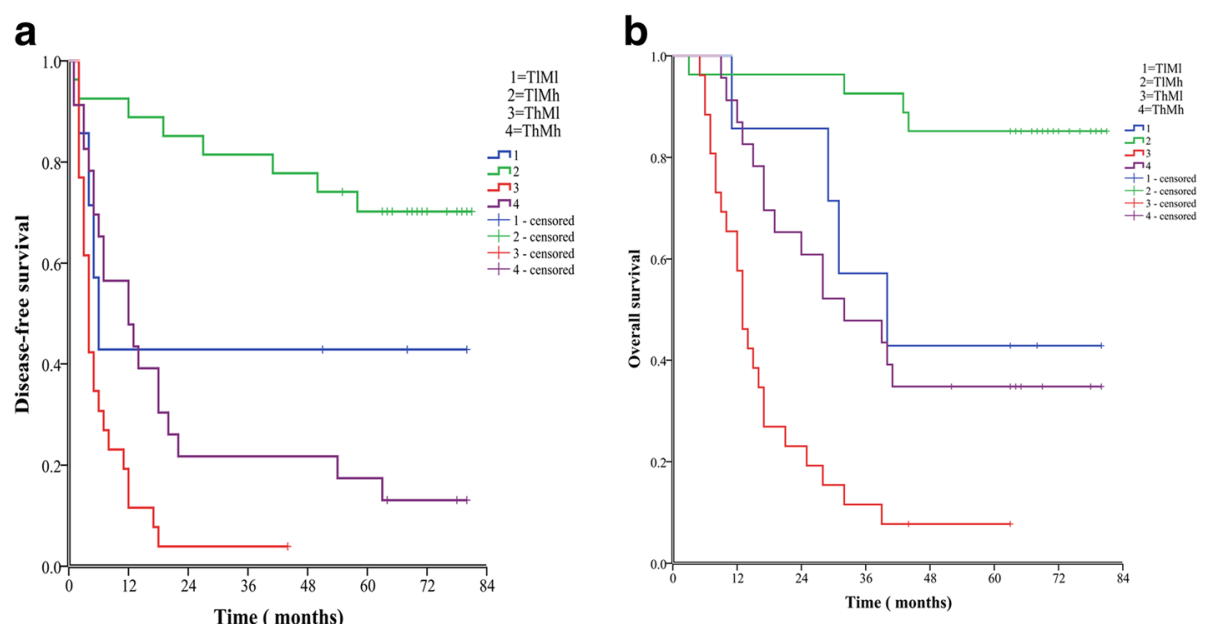

Fig. 5 The combination of c-Myc and TGF- $\beta 1$ was found to enhance prognostic accuracy for HCC. Disease-free survival curves (a, $P<0.001$, log-rank test) and overall survival curves (b, $P<0.001$, log-rank test)

associated with the poorest outcomes. In addition, the prognostic value of TGF- $\beta 1$ may be better than that of cMyc for patients with $\mathrm{HCC}$ with hepatectomy.

As for ELF and c-Myc, we found that patients with HCC with high ELF expression and high c-Myc expression had the best prognosis (3-year OS and DFS rates of $85.7 \%$ and $71.4 \%$, respectively), while the worst prognosis was seen in those with low ELF and low c-Myc expression (3-year OS and DFS rates of $9.1 \%$ and $0 \%$, respectively). The second best was in patients of low ELF and high cMyc expression (3-year OS and DFS rates of $54.5 \%$ and $31.8 \%$ respectively), and the third was in patients with high ELF and low c-Myc expression (3-year OS and DFS rates of $41.7 \%$ and $33.3 \%$, respectively). So we can conclude that low ELF expression or low c-Myc expression both predict a poor prognosis, and the worst outcomes are seen with low levels of both. In addition, the prognostic value of c-Myc may be better than that of ELF for patients with $\mathrm{HCC}$ with curative resection.

When all three markers were examined together, the worst outcomes were seen in patients with any combination of two or more of high TGF- $\beta 1$, low ELF, and low cMyc expression. The sequence of prognostic value of the three proteins for patients with HCC was TGF- $\beta 1>\mathrm{c}$ Myc $>$ ELF. The prognosis of patients of low TGF- $\beta 1$, high ELF, and high c-Myc expression was the best (3-year OS a

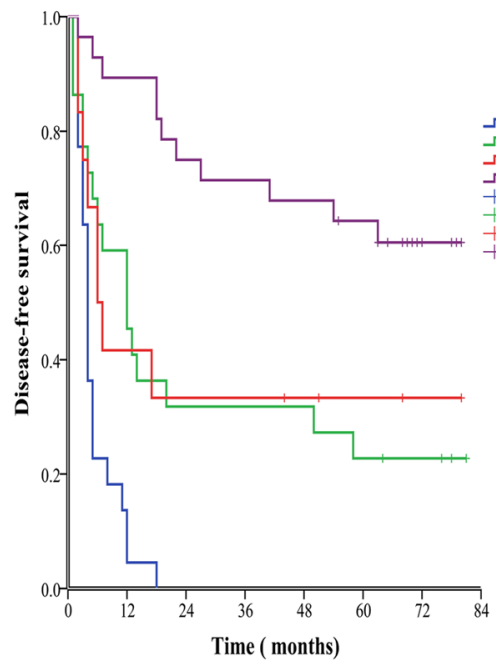

b

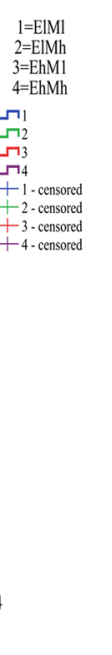

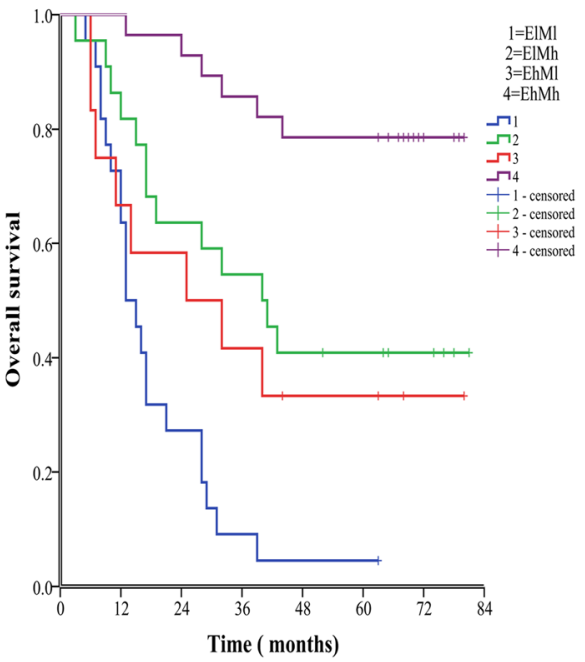

Fig. 6 The combination of C-Myc and ELF was found to enhance prognostic accuracy for HCC. Disease-free survival curves $(\mathbf{a}, P<0.001$, log-rank test) and overall survival curves (b, $P<0.001$, log-rank test) 

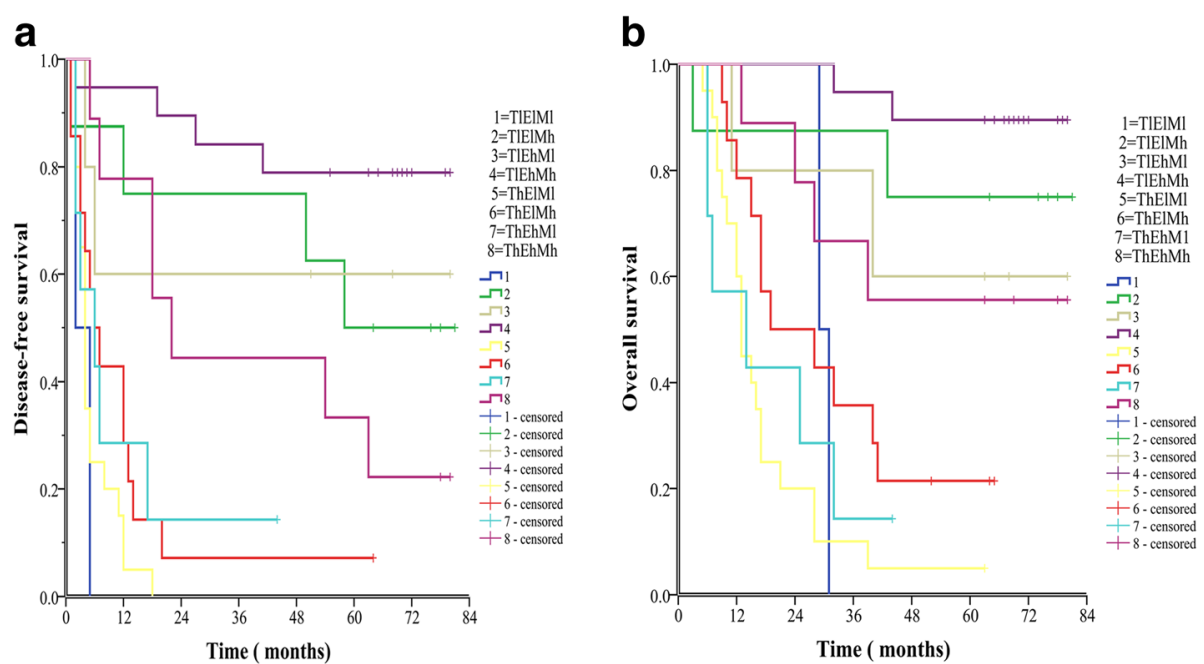

Fig. 7 The combination of c-Myc, TGF- $\beta 1$ and ELF was found to enhance prognostic accuracy for HCC. Disease-free survival curves (a, $P<0.001$, log-rank test) and overall survival curves (b, $P<0.001$, log-rank test)

and DFS rates of $94.7 \%$ and $84.2 \%$, respectively). The second best was seen in patients of low TGF- $\beta 1$, low ELF, and high c-Myc expression (3-year OS and DFS rates of $87.5 \%$ and $75.0 \%$, respectively), the third was in patients of low TGF- $\beta 1$, high ELF, and low c-Myc expression (3-year OS and DFS rates of $80.0 \%$ and $60.0 \%$, respectively), and the fourth was in patients of high TGF- $\beta 1$, high ELF, and high c-Myc expression (3-year OS and DFS rates of $66.7 \%$ and $44.4 \%$, respectively).

Based on our results, we speculate that c-Myc protein may play an important role in the process of HCC carcinogenesis, rather than sustaining the growth of the tumor cells. It may be one of the contributory mechanisms of HCC progression, i.e., the apoptosis of HCC cells is jeopardized by the diminished expression of $\mathrm{c}-\mathrm{Myc}$ and accompanying uncoordinated control of cellular growth. Low expression of c-Myc predicts short-term recurrence and a poor outcome in patients with $\mathrm{HCC}$, though there is c-Myc expression in most $\mathrm{HCC}$ tissues, whereas there is no $\mathrm{c}-\mathrm{Myc}$ expression in normal liver tissues. $\mathrm{c}-\mathrm{Myc}$ combined with TGF- $\beta 1$ or/and ELF can more accurately predict the prognosis in patients with $\mathrm{HCC}$, given the disruption of the TGF- $\beta 1$ signaling pathway is another important mechanism of HCC development. The combination of TGF- $\beta 1$, ELF, and $c-M y c$ expression is a valuable predictive method for outcomes in patients with HCC, which can usefully guide the follow-up and the further treatment for patients with HCC after curative resection. For instance, close follow-up should be performed to detect early tumor recurrence for the patients with any two or all of high TGF- $\beta 1$, low ELF, and low c-Myc expression in tumor tissues. Accordingly, the personalized comprehensive therapies should be provided for this kind of patients, such as TACE, chemotherapy, sorafenib and percutaneous ablation.

Certainly, this study still has several limitations and unanswered questions. First, our present study is a retrospective, single-institution study with a relatively small number of patients. A prospective and well-designed study with larger number of patients with $\mathrm{HCC}$ with radical surgery is needed. Second, why does the level of c-Myc expression in HCC tissues were lower than those in adjacent tissues? Why was the level of c-Myc in HCC tissues not correlated with TNM stage? Whether c-Myc plays the important roles on carcinogenesis and early stage of HCC? Thus, it is worthwhile to perform further studies to verify our findings and test their clinical application for patients with $\mathrm{HCC}$.

\section{Conclusion}

Our study demonstrates that low expression of c-Myc protein predicts poor outcomes in patients with $\mathrm{HCC}$ with hepatectomy. The combination of TGF- $\beta 1$, ELF and c-Myc can be used to accurately predict outcomes in patients with HCC. From a diagnostic point of view, our results prompt that the detection of $\mathrm{c}-\mathrm{Myc}$ alone or combining with ELF/ TGF- $\beta 1$ in tumor tissues could be a new prognostic marker in patients with HCC. We can depend on them to provide the personalized comprehensive therapies for patients with $\mathrm{HCC}$, especially patients with any two or all of low c-Myc, high TGF- $\beta 1$, and low ELF expression in tumor tissues. Further studies should be conducted to confirm our hypothesis that cMyc proteins play an important role on hepatocarcinogenesis and early stage of $\mathrm{HCC}$, and to elucidate the critical mechanisms of $\mathrm{c}-\mathrm{Myc}$ in $\mathrm{HCC}$. 


\section{Abbreviation}

AFP: Alpha-fetoprotein; Cl: Confidence interval; CT: Computed tomography; DFS: Disease Free survival; ELF: Embryonic Liver Fodrin; HBsAg: Hepatitis B surface antigen; HCC: Hepatocellular cancer; IRS: Immunoreactivity score; MRI: Magnetic resonance imaging; OS: Overall survival; PLT: Platelet; PVIT: portal vein tumor thrombi. HR: Hazard ratio; qRT-PCR: Real -time Quantitative Polymerase Chain Reaction; TACE: Transcatheter arterial chemoembolization; TGF- $\beta$ : Transforming growth factor $\beta$; TNM: Tumornode-metastasis

\section{Acknowledgements}

We thank Professor Mushfiquddin Khan (Department of Pediatrics, Medical University of South Carolina) for serious revision and providing insightful comments on this study.

\section{Funding}

This study was supported by grants from Science and Technology Program of Guangzhou (201707010387), the Science and Technology Project of Guangdong Province (No. 2014A020212626) and the Scientific Research Foundation for Returned Overseas Chinese Scholars, State Education Ministry $(2015$, no. 311).

\section{Availability of data and materials}

All data generated or analyzed during this study are included in this article. Also the data sets used and/or analyzed during the current study are available from the corresponding author upon reasonable request.

\section{Authors' contributions}

FJ, ZHZ, YZ and YPH were the main authors of the manuscript. They were involved in the conception, design and coordination of the study as well as in data analysis, interpretation of results and drafting the manuscript. YPH was in-charge of all experimental procedures. SLS, LJZ, QHC, SQL, BGP, and $L J$ participated in the experimental procedures and revised critically the content of the manuscript. All authors contributed to the interpretation of data and critically revised the manuscript. All authors read and approved the final manuscript.

\section{Ethics approval and consent to participate}

This study was retrospective study and approved by the Ethics Review Committee of the First Affiliated Hospital of Sun Yat-sen University. All participants provided written informed consent to participate.

\section{Competing interests}

The authors declare that they have no competing interests, and they consented to publish.

\section{Publisher's Note}

Springer Nature remains neutral with regard to jurisdictional claims in published maps and institutional affiliations.

\section{Author details \\ ${ }^{1}$ Pediatric Surgery, The First Affiliated Hospital, Sun Yat-sen University, Guangzhou 510080, People's Republic of China. ${ }^{2}$ Organ Transplant Center, The First Affiliated Hospital, Sun Yat-sen University, Guangzhou 510080, People's Republic of China. ${ }^{3}$ Department of Hepatobiliary Surgery, The Third Affiliated Hospital, Sun Yat-sen University, Guangzhou 510630, People's Republic of China. ${ }^{4}$ Department of Liver Surgery, The First Affiliated Hospital, Sun Yat-sen University, Guangzhou 510080, People's Republic of China. ${ }^{5}$ Department of Pathology, The First Affiliated Hospital, Sun Yat-sen University, Guangzhou 510080, People's Republic of China. 'Laboratory of Surgery, The First Affiliated Hospital, Sun Yat-sen University, Guangzhou 510080, People's Republic of China.}

Received: 14 December 2017 Accepted: 16 April 2018 Published online: 24 April 2018

\section{References}

1. Yao H, Bian X, Mao L, Zi X, Yan X, Qiu Y. Preoperative enteral nutritional support in patients undergoing hepatectomy for hepatocellular carcinoma: a strengthening the reporting of observational studies in epidemiology article. Medicine (Baltimore). 2015;94:e2006.
2. Ji F, Liang Y, Fu SJ, Guo ZY, Shu M, Shen SL, et al. A novel and accurate predictor of survival for patients with hepatocellular carcinoma after surgical resection: the neutrophil to lymphocyte ratio (NLR) combined with the aspartate aminotransferase/platelet count ratio index (APRI). BMC Cancer 2016; 22. 16:137.

3. Lozano R, Naghavi M, Foreman K, Lim S, Shibuya K, Aboyans V, et al. Global and regional mortality from 235 causes of death for 20 age groups in 1990 and 2010: a systematic analysis for the global burden of disease study 2010. Lancet. 2012;380:2095-128.

4. El-Serag HB, Rudolph KL. Hepatocellular carcinoma: epide $\neg$ miology and molecular carcinogenesis. Gastroenterology. 2007;132:2557-76.

5. Zhi X, Lin L, Yang S, Bhuvaneshwar K, Wang H, Gusev Y, et al. ßll-spectrin (SPTBN1) suppresses progression of hepatocellular carcinoma and Wnt signaling via regulation of Wnt inhibitor Kallistatin. Hepatology. 2015;61:598-612.

6. Pelengaris S, Khan M. The many faces of c-MYC. Arch Biochem Biophys. 2003;416:129-36.

7. Hoffman B, Liebermann DA. Apoptotic signaling by c-MYC. Oncogene. 2008; 27:6462-72

8. Meyer N, Penn LZ. Reflecting on 25 years with MYC. Nat Rev Cancer. 2008:8: 976-90.

9. Shiraha $H$, Yamamoto $K$, Namba M. Human hepatocyte carcinogenesis. (Review) Int J oncol. 2013;42:1133-8.

10. Cairo S, Wang Y, de Reyniès A, Duroure K, Dahan J, Redon MJ, et al. Stem cell-like micro-RNA signature driven by Myc in aggressive liver cancer. Proc Natl Acad Sci U S A. 2010;107:20471-6.

11. Dang CV. C-Myc target genes involved in cell growth, apoptosis, and metabolism. Mol Cell Biol. 1999;19:1-11.

12. Sakamuro D, Eviner V, Elliott KJ, Showe L, White E, Prendergast GC. C-MyC induces apoptosis in epithelial cells by both p53-dependent and p53independent mechanisms. Oncogene. 1995;11:2411-8.

13. Cook JR, Goldman B, Tubbs RR, Rimsza L, Leblanc M, Stiff $P$, et al. Clinical significance of MYC expression and/or "high-grade" morphology in nonBurkitt, diffuse aggressive B-cell lymphomas: a SWOG 59704 correlative study. Am J SurgPathol. 2014;38:494-501.

14. Nevzorova YA, Hu W, Cubero FJ, Haas U, Freimuth J, Tacke F, et al. Overexpression of c-myc in hepatocytes promotes activation of hepatic stellate cells and facilitates the onset of liver fibrosis. Biochim Biophys Acta. 2013:1832:1765-75.

15. Lin CP, Liu CR, Lee CN, Chan TS, Liu HE. Targeting c-Myc as a novel approach for hepatocellular carcinoma. World J Hepatol. 2010;2:16-20.

16. Frau M, Biasi F, Feo F, Pascale RM. Prognostic markers and putative therapeutic targets for hepatocellular carcinoma. Mol Asp Med. 2010;31:179-93.

17. Zimonjic DB, Popescu NC. Role of DLC1 tumor suppressor gene and MYC oncogene in pathogenesis of human hepatocellular carcinoma: potential prospects for combined targeted therapeutics. (Review) Int J Oncol. 2012;41: 393-406.

18. Ersahin T, Ozturk M, Cetin-Atalay R. Molecular Biology of Liver Cancer. Rev Cell Biol Mol Med.2015;1:206-43

19. Wang $Y$, Wu MC, sham JS, Zhang $W$, Wu WQ, guan $X Y$. Prognostic significance of cmyc and AIB1 amplification in hepatocellular carcinoma. A broad survey using high-throughput tissue microarray. Cancer. 2002; 95:2346-52

20. Srivastava J, Siddiq A, Gredler R, Shen XN, Rajasekaran D, Robertson CL, et al. Astrocyte elevated gene-1 (AEG-1) and c-Myc cooperate to promote Hepatocarcinogenesis. Hepatology. 2015:61:915-29.

21. Srivastava J, Siddiq A, Gredler R, Shen XN, Rajasekaran D, Robertson CL, et al. MYC inactiva $\neg$ tion uncovers pluripotent differentiation and tumour dormancy in hepatocellular cancer. Nature. 2004;431:1112-7.

22. Bouchard C, Lee S, Paulus-Hock V, Loddenkemper C, Eilers M, Schmitt CA FoxO transcription factors suppress Myc-driven lymphomagenesis via direct activation of Arf. Genes Dev. 2007;21:2775-87.

23. Finch A, Prescott J, Shchors K, Hunt A, Soucek L, Dansen TB, et al. BCl-xL gain of function and p19 ARF loss of function cooperate oncogenically with Myc in vivo by distinctmechanisms. Cancer Cell. 2006;10:113-20.

24. Pelengaris S, Khan M, Evan Gl. Suppression of Myc-induced apoptosis in beta cells exposes multiple oncogenic properties of Myc and triggers carcinogenic progression. Cell. 2002;109:321-34.

25. Murakami H, Sanderson ND, Nagy P, Marino PA, Merlino G, Thorgeirsson SS. Transgenic mouse model for synergistic effects of nuclear oncogenes and growth factors in tumorigenesis: interaction of c-myc and transforming growth factor alpha in hepatic oncogenesis. Cancer Res. 1993;53:1719-23. 
26. Lee JS, Chu IS, Mikaelyan A, Calvisi DF, Heo J, Reddy JK, et al. Application of comparative functional genomics to identify best-fit mouse models to study human cancer. Nat Genet. 2004;36:1306-11.

27. Kaposi-Novak P, Libbrecht L, Woo HG, Lee YH, Sears NC, Coulouarn C, et al. Central role of c-Myc during malignant conversion in human hepatocarcinogenesis. Cancer Res. 2009;69:2775-82.

28. Akita H, Marquardt JU, Durkin ME, Kitade M, Seo D, Conner EA, et al. MYC activates stem-like cell potential in Hepatocarcinoma by a p53-dependent mechanism. Cancer Res. 2014;74:5903-13.

29. Murphy DJ, Junttila MR, Pouyet L, Karnezis A, Shchors K, Bui DA, et al. Distinct thresholds govern Myc's biological output in vivo. Cancer Cell. 2008; 14:447-57.

30. Ji F, Fu SJ, Shen SL, Zhang LJ, Cao QH, Li SQ, et al. The prognostic value of combined TGF- $\beta 1$ and ELF in hepatocellular carcinoma. BMC Cancer. 2015:15:116.

31. Hua YP, Yin XY, Peng BG, Li SQ, Lai JM, Liang HZ, et al. Mechanisms and influence of octreotide-induced regulation of somatostatin receptor 2 on hepatocellular carcinoma. Chemotherapy. 2009;55:312-20

32. Hua YP, Li SQ, Lai JM, Liang $L$, Peng BG, Liang HZ, et al. Changes in TGF- $\beta$ / Smads signaling pathway in rats with chemical hepatocarcinogenesis. J South Med Univ. 2008;28:1848-52.

33. Santoni-Rugiu E, Jensen MR, Factor VM, Thorgeirsson SS. Acceleration of Cmyc-induced hepatocarcinogenesis by co-expression of transforming growth factor (TGF)-alpha in transgenic mice is associated with TGF-beta1 signaling disruption. Am J Pathol. 1999;154:1693-700.

34. Jin J, Zhu P, Liao Y, Li J, Liao W, He S. Elevated preoperative aspartate aminotransferase to lymphocyte ratio index as an independent prognostic factor for patients with hepatocellular carcinoma after hepatic resection. Oncotarget. 2015;6:19217-27.

35. Cui J, Dong BW, Liang P, Yu XL, Yu DJ. Effect of c-myc, Ki-67, MMP-2 and VEGF expression on prognosis of hepatocellular carcinoma patients undergoing tumor resection. World J Gastroenterol. 2004;10:1533-6.

36. Yuen MF, Wu PC, Lai VC, Lau JY, Lai CL. Expression of C-Myc, c-Fos, and cJun in hepatocellular carcinoma. Cancer. 2001;91:106-12.

37. Tabrizian P, Jibara G, Shrager B, Schwartz M, Roayaie S. Recurrence of hepatocellular Cancer after resection: patterns, treatments, and prognosis. Ann Surg. 2015;261:947-55

\section{Ready to submit your research? Choose BMC and benefit from}

- fast, convenient online submission

- thorough peer review by experienced researchers in your field

- rapid publication on acceptance

- support for research data, including large and complex data types

- gold Open Access which fosters wider collaboration and increased citations - maximum visibility for your research: over $100 \mathrm{M}$ website views per year

At BMC, research is always in progress.

Learn more biomedcentral.com/submissions 